\title{
Erik Flensted-Jensen - facetter af et livsværk
}

\author{
af Finn Berggren
}

Da det den 21. januar 1993 blev kendt, at den 84-årige gymnastik- og rejseleder Erik Flensted-Jensen var sovet ind gled en række billeder og episoder frem af min hukommelse, og sammen med følgende levnedsskildring bidrager de til at vise facetter af en personlighed og hans livsværk.

De mange gymnastikture vil ikke blive beskrevet $\mathrm{i}$ detaljer, da dette på fyldig vis er varetaget i Flensteds egne bøger. Følgende punktvise nedslag i Flensteds liv og virke er den palet, hvorfra der tegnes et billede af en person, hvis liv forblev kædet sammen med gymnastikken.

\section{Gymnasten}

- mødet med Niels Bukh og Ollerup

Der er en Oplevelse fra min Drengetid, jeg ofte har tænkt på, mens jeg var paa Rejse med Niels Bukh i Jordens fjerneste Egne.

Til min barndomsby Vordingborg kom engang et Hold Folkedansere - ikke voksne, men Drenge og Piger på min egen Alder. De gav opvisning på Hotel Valdemar, og så vidt jeg husker, gjorde de stormende Lykke. Der var navnlig een Dans, jeg lagde Mærke til. Det var Degnedansen.

Jeg husker, at jeg, da vi gik Hjem, sagde til Moder: "Tror du ikke nok, jeg kunde komme med paa saadan et Hold engang og rejse - bare til Nastved?"

At mine Dromme blev mere end opfyldte, at jeg blandt andet har faaet Lov til at danse den selv samme Dans, som dengang gjorde så starkt Indtryk påmig, for tusindtallige brogede Tilskuerskarer $i$ Østens fagre Riger - derfor takker jeg Niels Bukh, Skaberen af Ollerup Gymnastikhøjskole.

Erik Flensted-Jensen (Indledning i Med Niels Bukh Jorden Rundt
Erik Flensted-Jensen begynd te som 16 årig i forberedelsesklassen på Vordingborg Seminarium i august 1924, men netop dette efterår oplevede den unge Flensted en skelsættende begivenhed, der kom til at indvirke på hele hans livsforløb. Gymnastiklederen fra Ollerup, Niels Bukh besøgte Vordingborg med sit "Pariserhold“ 1).

Opvisningen og samtaler med gymnaster på holdet overbeviste Flensted om, at han ville på Ollerup med det samme. Der lå yderligere et incitament til grund for denne hurtige beslutning: rygtet sagde, at Niels Bukh sandsynligvis skulle en tur til Ægypten det følgende efterår. Eventyr-og rejselysten trængte sig på. Ægyptensturen blev imidlertid ikke til noget, men det gjorde opholdet på Ollerup fra januar 1925. Det var et tre måneders ophold, men da Niels Buhk opfordrede elever til at blive på skolen sommeren over for at medvirke ved bygningen af Danmarks førstesvømmehal, var Flensted én af dem, der meld te sig for en dagløn på 3 $\mathrm{kr}$, men samtidig en ekstra „løn" $\mathrm{i}$ form af yderligere undervisning og træning i gymnastik.

Indtil nu havde den største udenlands oplevelse for Flensted været en cykeltur til Kullen, men i efteråret 1925 deltog han i sin første gymnastikrejse med Niels Bukh til Tyskland og Tjekkoslovakiet.

Det er et mærkeligt sammentræf, at de fortløbende diskussioner om berettigheden af gymnastikture første gang bliver kommenteret i forbindelse med netop denne udenlandsrejse, hvor Flensted for første gang er med som gymnast. Kristian Krogshede afslutter således sin beskrivelse af netop denne tur med:

Der lyder undertiden roster om, at Niels Bukh burde holde op med disse ture og samle sig helt om den danske ungdoms sag, også i de måneder, 
der ligger uden for skoletiden. Men vurderer man nærmere, hvad der kommer ud af turene, vil man forstå deres betydning. I USA var man blevet så optaget af dansk gymnastik, at der nu planlagdes særlige kursus for amerikanere. I Finland havde kaptajn Levälahti udtalt, at den primitive gymnastik havde vundet hævd i deres største ungdomsbevxgelse Skyddskårene.ITyskland var Niels Bukhs bog udkommet $i 6$ oplag, og primitiv gymnastik dyrkedes $i$ alle egne af landet. Det var således med god grund, man drog ud på disse nutidens fredelige vikingetogter". 2)

Flensteds studietid på seminariet i Vordingborg blev atter afbrudt af gymnastikkens fristelser, idet han i efteråret $1927 \mathrm{ikke} \mathrm{kunne}$ modstå lysten til at deltage i Niels Bukhs gymnastikturne til Island, Tyskland, Holland, England og Skotland. På denne tur var Flensted gymnast sammen med to andre kendte gymnastikkoryfæer, Kristian Krogshede, Niels Bukhs højre hånd indtil 1936 og grundlæggeren af Gerlev Idrætshøjskole, og Mads Nielsen, der senere blev forstander på Gymnastikhøjskolen vedViborg. Alle tre blev gymnastiske inspiratorer og pejlemærker for generationer af gymnastikinteresserede.

\section{Gymnastikken forbliver hovedinteressen}

Flensteds uddannelse til sin lærergerning fik et ret usædvanligt forløb. De første 3 år af seminarietiden, inclusive forberedelsesklassen, blev afviklet på Vordingborg Statsseminarium med flere længerevarende fravær, og skoleåret 1928-29 blev nærmest gennemført som en dobbeltgænger, idet Flensted var indskrevet på Statens Gymnastikinstitut og gennemførte med udmærkelse, samtidig med at det tredje og afsluttende år på seminariet blev afviklet på Blågård Seminarium i København.

Flensteds lyst til at frigøre sig fra sine studier og sit virke som lærer for at kunne deltage i træning og gymnastikrejser fortsætter på samme vis som under seminarietiden. De første år som lærer i Gentofte blev ikke, hvad han havde forventet, og Flensted beslutter sig til at tage et et-årigt studenterkursus i København, men for at klare dagen og vejen må han virke som fast årsvikar i Københavns skolevæsen. Lyspunkterne og hovedinteressen er stadig gymnastikken. I foråret 1930 får Flensted fri til at deltage i Niels Bukhs opvisnings-og instruktionsrejse til Tyskland, Østrig og Ungarn, og i marts 1931 har Flensted orlov for at kunne lede et 3 ugers kursus i gymnastik på KFUM's Internationale Idrætsskole i Genéve. Flensted fortæller i sin bog Med Niels Bukh Jorden Rundt, hvilke tanker, der rørte sig i ham på vejen til Geneve:

Jeg gladede mig til dette Arbejde, min forste selvstændige Opgave som Gymnastikinstruktor uden for Danmarks Grænser. Ud over den Spænding, hvormed jeg naturligvis imødeså dette Hverv, var der også en anden Ting, der voldte mig en vis Uro: Efter at det var blevet bestemt, at jeg skulle tilbringe Størstedelen afMarts Maaned $i$ Geneve, havde jeg modtaget Gymnastikhøjskolens Aarsskrift for 1930. Det indeholdt følgende kortfattede, men for en rejselysten ung Mand yderst tillokkende Meddelelse fra Niels Bukh: Alle de "O.D."er, hvis gymnastiske - og øvrige Forhold muliggør Deltagelse i Turen, Jorden rund $t^{\prime}$, beder jeg skrive til migom dette, da jeg vil ind byde til frit Træningsophold her for mandlige i Marts og for kvindelige i Juli, saa de kan faa Lejlighed til sammen med nuværende Vinterskoles og kommende Sommerskoles Elever at forsøge Optagelse som Deltagere på Holdene. 3)

Lysten sejrede, og den gymnastiske kunnen bevirkede, at Flensted var én af de 26 heldige, der den 5. august 1931 lagde ud på en for datiden ufattelig 41/2 måneds turné jorden rundt. Hovedmålet var Japan, men rejsen omfattede også Danzig, Estland, Letland, Litauen, Sovjetunionen, Manchuriet, Korea, Canada, USA og England.

Det blev en utrolig oplevelse for gymnasterne og Flensteds beskrivelse af den mest besøgte opvisning på turen giver et fint holdnings- og stemningsbillede 4). Opvisningen fandt sted i Koreas hovedstad, Seoul, der på det tidspunkt var under japansk administration:

Dagens største Oplevelse blev dog vor Opvisning, som fandt Sted Kl.1 om Eftermiddagen paa et kxmpemæssigt Stadion, der var smykket med en Kreds af store japanske og danske Flag. Allerede Kl. 11, da vi var ude for at se paa Pladsfor- 
hold og Redskaber, strømmede Folk til i Tusindvis; de stod ligefrem $i \mathrm{~K} ø$ for at komme ind.

Da vi Kl.1 marcherede ind bag Dannebrog, syngende "Vaj højt, vaj stolt og frit vort Flag", da var hele det valdige Stadion tæt besat med Mennesker. Brune Ansigter - Hoved ved Hoved - $i$ Titusindvis $i$ en mægtig Kreds omkring os. Det var fremmedartede Folkeslag: Koreanerne $i$ hvide Kapper og Japanerne i brogede Kimonoer eller europæiskTøj.Desad ikke itilfæeldig Orden, men var ordnet gruppevis, saa det store Hav af Tilskuere næsten var inddelt $i$ Felter, mørke, lyse eller spraglede, alt efter de Dragter, som de forskellige Mennesker var klædt i. Der var store Grupper af Studenter, der var Pige- og Drengeskoler, der var militære saavel som civile. Der var 30.000 Tilskuere til Stede paa Stadion, og endda sad en Mængde Mennesker paa Skrænter og Høje udenfor Hegnet. Alle hilste de os med bragende Klapsalver, saa snart de saa det forste Glimt af vor Fane. Solen brændte fra en nasten skyfri Himmel, og paa alle sider løftede skønne Bjergryggesigover Horisonten. En Flyverdronede frem og tilbage $i$ store Sving lavt over vore Hoveder som en Velkomsthilsen til os og tillige for at optage Fotografier til de japanske Aviser. Svarme af Brevduer blev sendt op. De spredte Niels Bukhs Berømmelse over Korea ved at flyve ud med Bud om de danske Gymnaster til Halvoens mange Dagblade.

Vi marcherede forst en Runde over Lobebanen, mens Bifaldet brusede os i Møde, efterhaanden som vi kom frem. Denne Indmarch glemmer jeg aldrig. Jeg saa og saa paa de mange Tusinder af Mennesker, der var samlet om os. Jeg saa paa de venlige ansigter, der straalede os $i$ møde. Jeg saa paa den skønne, storslaaede Natur, der omgav os, og jeg saa paa vor smukke Fane, der blev baaret frem midt imellem alt det fremmedartede omkring os.

Jeg er ikke i mindste Maade i tvivl om, at disse Minutter for mig var Turens storste og mest bevægede Øjeblikke ude i det fremmede.

I en saadan Stund foler man, at man er dansk. Man foler det med Stolthed og med Glade ;men man foler det også som en Forpligtelse, ikke en Pligt der tynger, men en mærkelig blanding af Pligt, Lyst og Evne til at give sig $i$ kast med Opgaver til Gaun for andet og andre end ens eget Jeg. - Jeg tror bestemt, at den slags store øjeblikke er en hemmelig Drivkraft i et Menneskes fremtidige Liv og Arbejde.

\section{Forfatteren, foredragsholderen og fotografen}

Tilbageblik:

$V i$ er i midten af 50'erne. Alle mine kammerater fra gymnastikholdet sad samlet på de opstillede stole i den tætpakkede Vordingborghal og kikkede spændt på foredragsholderen, der baksede med sin filmfremviser inden arrangementet skulle begynde. Vores gymnastikleder havde fortalt, at vi kunnese frem til en stor oplevelse, idet Gymnastikforeningen havde inviteret én af foreningens og byens kendte sønner, Erik Flensted-Jensen, til at vise sin film "Flik-Flak gennem Amerika".

Vores gymnastikleder fik ret, for selv om filmen på det tidspunkt var flere år gammel og skildrede gym-nastikturneen til USA, Canada og Cuba, 1946-47, og havde varet vist flere gange i foreningen, sad vi fulde huse og lod rejseindtrykkene og Flensteds medlevende kommentarer satte dybe spor.

\section{Bogerne}

Flensted havde æstetisk sans. Det gav sig ikke alene udtryk i en kritisk gymnastisk holdning, men også i den skriftlige og visuelle produktion. Han arbejdede meget med udtryksformen, og resultatet blev en oplevelse for øjet og øret.

Flensteds bogudgivelser, filmproduktion, fotosamling og foredragsvirksomhed blev i mange år den væsentligste indtægtskilde til forsørgelse af familien. Det var imidlertid ikke nogen let sag. Ikke uden lune fortalte Flensted om sit ægteskab med Elise Schmitt, dagligt kaldet Lise, at de kort efter giftemålet i 1936 blev ængstelige for, at deres ægteskab skulle blive barnløst. Slet så galt gik det ikke, da de i løbet af 14 år fik 8 børn.

Forfatterskabet strækker sig over en lang periode. Den første bogudgivelse Med Niels Bukh jorden rundt er en særdeles velskreven og detaljeret rejsebeskrivelse af den imponerende gymnastikturné med Niels Bukh i 1931 5). 


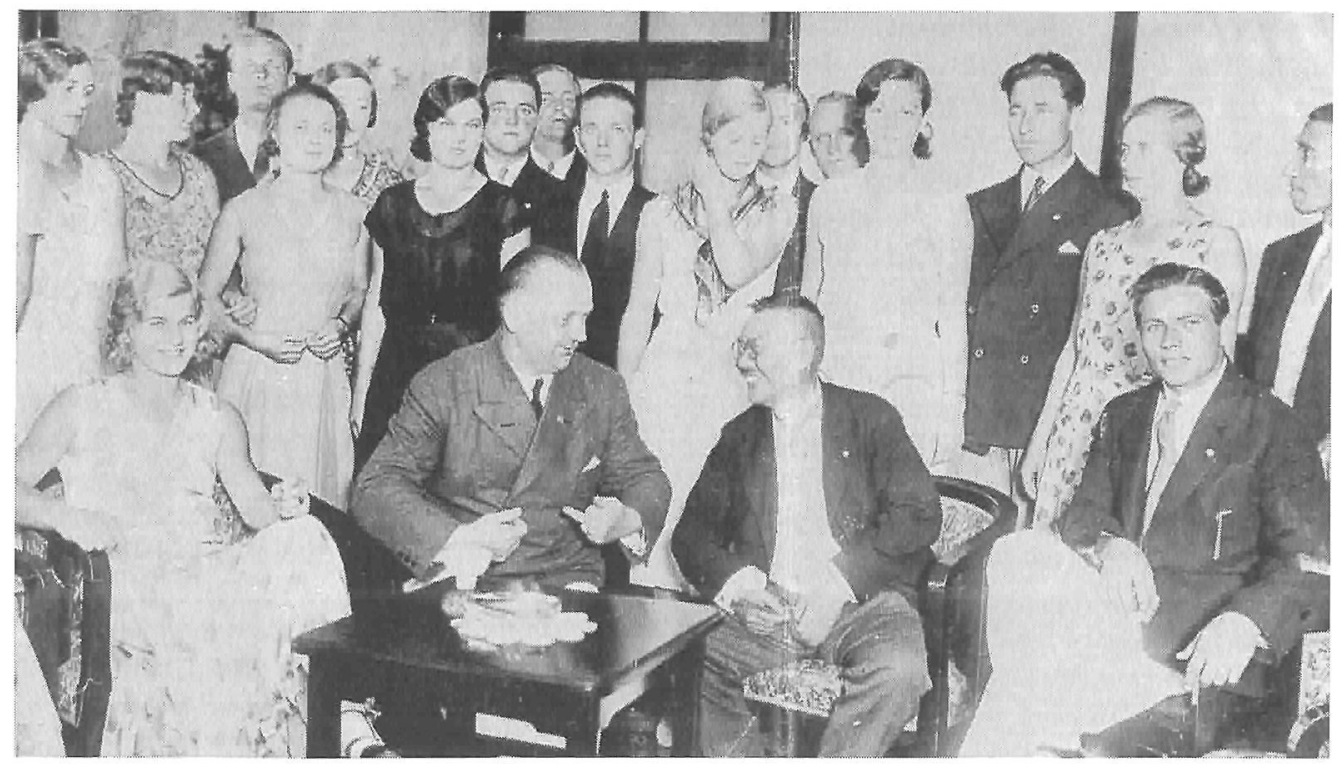

Den japanske undervisningsminister Ryuzo Tanaka modtager de danske gymnaster under turneen i Japan. Til venstre forundervisniugsministeren sidder Niels Bukh, og yderst til højre sidder Erik Flensted-Jensen

På flere måder gav Niels Bukh udtryk for sin glæde over det store arbejde, der lå bag udgivelsen af denne bog. I et personligt brev til Flensted formulerer han sin taknemmelighed:

Du har gledet mange, mange Mennesker med den (bogen), og måskemest mig! og ialle Tilfxlde har du gavnet mig mere end andre. (understregningerne er Niels Bukhs) 6).

Forordet i Med Niels Bukh jorden rundt er også forfattet af Niels Bukh og er ofte blevet citeret af Flensted, måske fordi det kunne stå som overskrift for hele Flensteds liv og virke:

Vikingefarden til fjerne Lande Jorden rundt, som denne Bog fortæller om, drog vi ud på med Ønske om pa vor Vis at gøre Danmark større og med Vilje til efter bedste Evne at satte dansk Præg på Ungdomsarbejdet blandt de Folk, vi kom i forbindelse med.

Det var ikke nyt for Flensted at sætte sine rejseoplevelser på skrift. Danske aviser nød i tyverne stor glæde af Flensteds rejseberetninger fra de fire mindre gymnastikturneer med Niels Bukh, og grundlaget for bogen Med Niels Bukh jorden rundt begyndte også som rejseberetninger til aviserne.
Evnen til at begejstre læserskaren med sine rejsebeskrivelser afspejles også i de to følgende bøger. Den første bog 40.000 kilometer under Dannebrog - Med Amerika-Drengene til Vestindien, USA og Canada beskriver Flensteds første rejse med et udvalgt drengehold i sidste halvdel af 1939 7), og udkom efter aftale med Kong Christian den X. på kongens fødselsdag den 26. september 1945, i anledning af at kongen havde været protektor for turen 8 ).

Den anden Med dansk Ungdom i Amerikas brogede verden - En gymnastikturnè til USA, Canada og Cuba omhandler Flensteds første turné med et fælleshold - 18 piger og 19 mænd - der i august 1946 påbegyndte halvanden års gymnastikturné, iøvrigt den længste af alle Flensteds gymnastikturneer 9).

Flensteds 3 første bøger, der udkom inden for et tidsspand af 20 år, blev tilsammen solgt i et oplag på over 50.000, hvilket efter dansk målestok må siges at være særdeles flot.

Den sidste bog fra Flensteds hånd,Mit liv og mine rejser 10), udkom 30 år senere $\mathrm{i}$ 1983 og giver en meget personlig beskri- 
velse af Flensteds opvækst under trange kår i et kristent hjem i Vordingborg, hans kristne tro og religiøse udvikling samt beskrivelse af alle gymnastikturneer fra 1939 til 1981. Den eneste gymnastikturné, som Flensted har været direkte involveret $i$, der aldrig har fået et skriftligt ord med på vejen, er en mindre turné til Vestindien og Puerto Rico i januar 1989.

I en alder af 74 begyndte Flensted på ny at sælge sin sidste bog ved foredragsvirksomhed og personlig kontakt, men en mindre hjerneblødning satte tempoet væsentligt ned. Det var iøvrigt med stor beklagelse, at Flensted til sidst måtte erkende, at der ikke var noget amerikansk forlag, der ville påtage sig at stå for en udgivelse af den 400 sider store bog Mit liv og mine rejser, som han havde fået oversat til engelsk. Interessen for personlige rejseoplevelser var ikke i højsædet.

\section{Billedsiden}

For alle gymnaster, der har rejst med Flensted, var det at opleve Flensted med sit skudklare kamera en naturlig del af enhver sightseeing. I bogen Med dansk ungdom $i$ Amerikas brogede verden giver Flensted selv en rammende beskrivelse af en situation, som alle deltagere på denneog senere turneer kan nikke genkende til:

Gang på gang måtte jeg standse for at nyde det herlige udsyn. Høje nikkende blomsterstande af yuacca eller agave $i$ den nærmeste forgrund kunne tit give billedet et særligt perspektiv, og det var jeg altid interesseret $i$; jeg havde jo filmsapparat med. Jeg skal nu gerne indromme, at det ikke var lutter fornojelse at vare filmsfotograf på denne vandretur. For at få de helt rigtige motiver måtte jeg ustandselig vare på txerne, snart foran holdet og snart bagved, snart på maven i en kløft under stien og snart oppe på en klippetop højt over de andre; ellers var filmen blevet alt for kedelig at se på, men det tog unxgtelig på kræfterne. 11)

Resultatet af Flensteds evner som fotograf afspejler sig dels i de mange fotos, der indgår i bogudgivelserne, dels i reklamebillederne til de mange Danish Gym Teams programmer, der er blevet udarbejdet gennem årene. Familien kan stadig fortælle om, h vor- dan stuerne blev omdannet til redigeringslokaler, når nye billeder og tekst skulle udvælges og samles efter meget store æstetiske krav. Flensted var bevidst om selv den mindste detalje.

Rejsefilmenes succes taler sit eget sprog.

Fra den første turne havde Flensted fremstillet en lille "Amerika-film", men det var de følgende to film, der rigtig fik opmærksomhed fra pressen.

Turneen i 1946-47 gav baggrunden til filmen Flik-flak gennem Amerika der blev færdigredigeret kort efter turens ophør, mens bogen om samme tur Med dansk ungdom i Amerikas brogede verden først udkom i 1952.

Filmen var en kæmpesucces overalt i Danmark. Den blev vist i de største haller og i næsten hvert eneste forsamlingshus. Udover Flensted selv rejste gymnnaster rundt med fem kopier af filmen.

Efter at filmen første gang var blevet vist i Århus-hallen for ca. 3000 mennesker, skrev Århus Stiftstidende:

Filmen varede to timer og måtte gerne have varet to til. Filmen kan fylde Arhushallen en gang til, eventuelt med de samme som var der $i$ aftes. 12) Anmelderen fik ret, for Århushallen blev atter fyldt og ikke kun to, men otte gange. Flensted citerer Jyllands-Postens anmeldelse af den samme filmfremvisning i Mit liv og mine rejser:

Hvorfor ikke også vise denne film for skolebørnene? Det er geografi og underholdning i fornøjeligste form, og det er en fortxlling om, at dansk ungdom er istand til at vakke begejstring ude i den store verden. 12)

Årsagen til at netop denne film Flik-flak gennem Amerika fik så stor succes, begrunder Flensted selv med, at det for det første var en usædvanlig rejse, der i tid varede næsten halvandet år og i udstrækning var dobbelt så lang som jordens omkreds ved ækvator. Hertil kom, at filmen blev vist på et tidspunkt så hurtigt efter besættelsen, at alle stadig hungrede efter at se nyt ude fra den store verden, og ikke mindst fra Amerika, og endelig var filmens farver og tekniske side af usædvanlig god kvalitet.

Flensteds anden store rejsefilm Flik-Flak $i$ tropesol omhandler turen jorden rundt $\mathrm{i}$ 
1955. Faktisk optog Flensted så meget $16 \mathrm{~mm}$ råmateriale, at der var nok til to helaftensfilm, med det resultat, at Flensted besluttede, at den del af turen der omhandlede besøget på Fiji-øerne, Australien og det meste af Ceylon skulle indgå i anden del. Imidlertid oplevede Flensted, at den første del FlikFlaki tropesol fikså strålende anmeldelser og blev en så stor tilskuer succes, at han rejste rundt så længe med filmforevisninger, at der aldrig blev tid til at færdiggøre del to.

\section{Foredragsvirksomhed}

Foredrag og filmfremvisninger blev en væsentlig del af Flensteds tilværelse. Turen med Niels Bukh og den deraf følgende bog Med Niels Bukh jorden rundt gjorde, at han blev en meget benyttet foredragsholder. I „Dagens Nyheder" kunne man således den 4. februar 1932 læse følgende overskrift „Et Mønsterforedrag af Hr. Flensted-Jensen " og Fyns Stiftstidende skriver samme år:

Flensted-Jensen er en udmarket Foredragsholder. Paa sin ligefremme og naturlige Maade fortalte han om Bukh, om Skolen og om de Rejser, som, Høvdingen' $i$ Ollerup har fort sine Gymnaster ud paa. Dels ved Lysbilleder og dels ved en udmærket Smalfilm illustrerede han sine Indtryk paa en Maade, så Publikum ikke kunne andet end begejstres. 13)

Til gengæld tabte Flensted gradvis begejstringen for at være lærer og sagde i $1944 \mathrm{sin}$ stilling ved Hellerup Skole op for herefter at arbejde fuldtids med at planlægge den næste gymnastikturné og samtidig ernære sig ved foredragsvirksomhed:

Udstyret med en magtig bagage bestående med både lysbilled-og filmsapparat og meget andet drog jeg dengang landet rundt med mit foredrag "40.000 kilometer under Dannebrog."

Det var ikke lutter spog at rejse i de dage, navnlig ikke med en så omfangsrig bagage som min. I begyndelsen stampede jeg mig frem på cykel med min påhængsvogn; men da det efter nogen tids ikke helt ubetydelige anstrengelser viste sig, at det var umuligt at få gummilaserne på påhængsvognens hjul til at holde til den store vagt, måtte denne form for transport opgives. Istedet begyndte jeg at tage med tog eller rutebil, hvorved jeg dog alligevel ikke blev sparet for ubehagelige overraskelser. Det var naturligvis altid kedeligt for de rejsende, når det viste sig, at der manglede nogle skinner foran lokomotivet, så man màtte vandre et par hundrede meter eller mere for at komme over $i$ et andet tog; men varre var det selvfølgelig, når man også skulle slabe på en oppakning, der var tung nok til at tvinge selv et mulddyr $i$ knæ. Indskrevet gods kunne man aldrig vare sikker på at få $i$ rette tid, så jeg foretrak altid at have det hele med som håndbagage. Det var ikke særligt behageligt, når man skulle undersøges af tyskerneved Storebælt, eller når toget var så overfyldt, at man måtte ind gennem et vindue for at komme med.... Skal jeg vare helt ærlig, må jeg dog tilstå, at der engang var en salfuld mennesker på Mors, der ventede tålmodigt $i$ halvanden time, fordi der pludselig var forsvundet en bro foran mig ved Langä; men frem nåede jeg. Det er ganske vist også passeret, at forsamlingshuset var roget i luften, når jeg kom for at vise min Amerikafilm; men så fandt bestyrelsen for den pågxldende gymnastik-eller ungdomsforeninget andet hus, der kunne benyttes $i$ stedet." 14)

I slutningen af 40'erne og i 50'erne blev foredrags og filmforevisninger den væsentligste indtægtskilde, men til trods for den store succes, filmen Flik-Flak itropesol havde i slutningen af 50'erne, blev det efterhånden klart for Flensted, at fjernsynet ville blive en for stærk konkurrent, med det resultat at Flensted ikke længere producerede kostbare rejsefilm fra de følgende ture. Der blev dog i 1963 produceret en $16 \mathrm{~mm}$ farve- og tonefilm af et helt opvisningsprogram, som blev fremvist og benyttet som inspirationsmateriale i Amerika, Australien, New Zealand og Japan. Den blev senere beskåret til en mindre version af 20 minutters varighed.

Flensted fortsatte med at holde foredrag til langt op i årene og ikke uden visse pudsigheder. Han skulle således for et par år siden som 82 årig holde fordrag og vise film på en efterskole. Det, der i første omgang vakte opmærksomhed, var filmfremviseren, som Flensted havde brugt siden 50'erne og den gamle spolebåndoptager, som Flensted skulle synkronisere med filmen. Men til trods for de mange år på bagen gjorde filmen også denne gang stor lykke. 


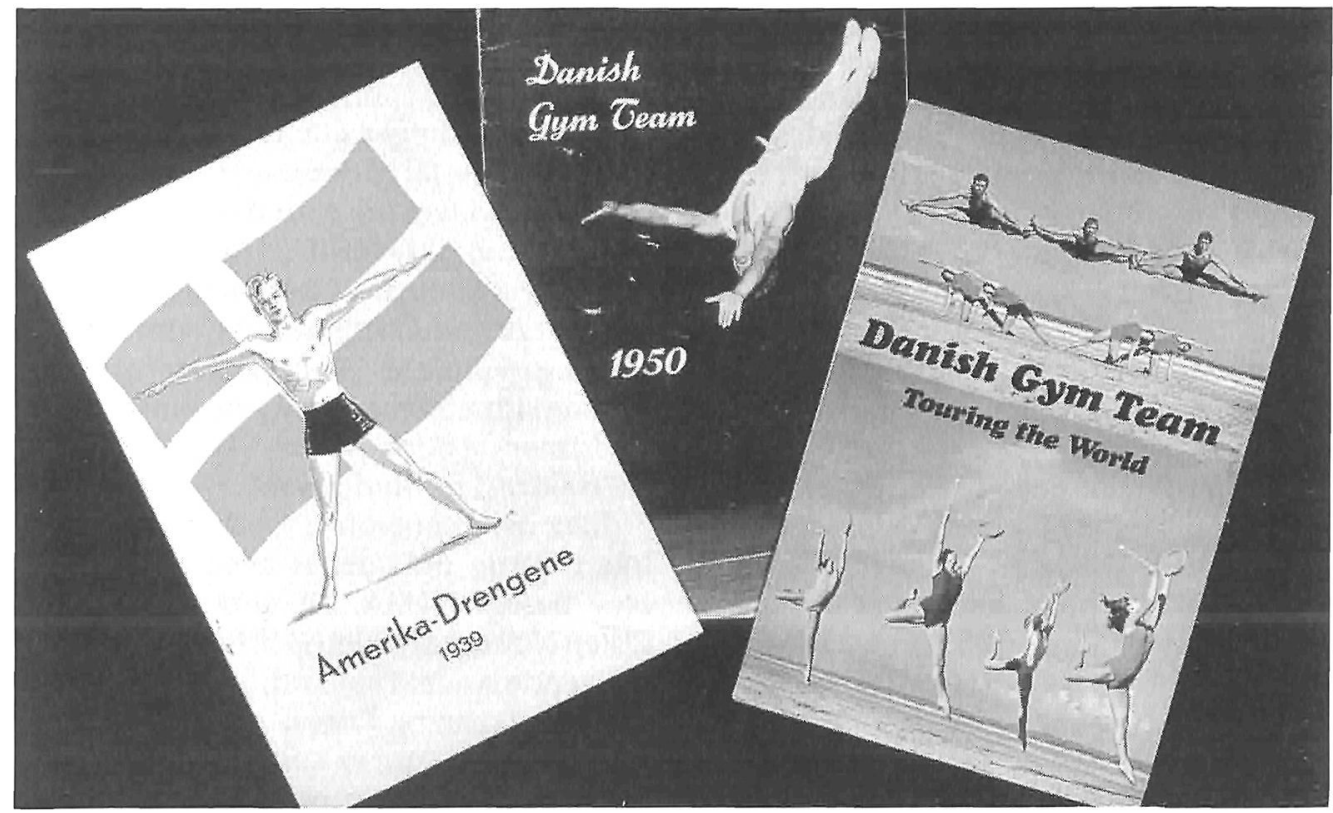

Eksempler på programmer fra den første turne i 1939 til det sidste officielle program i 1976-77. Forsiden på sidstnæonte program blev også brugt som plakat.

\section{Eventyreren og rejselederen}

\section{Tilbageblik}

Efteråret 1976. Flensted er atter på turnéi USA. Til trods for Flensteds utallige besøg i det samme omraide sikrer han sig, at vores karavane af biler med gymnaster standser ved alt, der kan have den mindste historiske eller naturmæssige interesse. En tur langs den californiskekyst, Highway One, kan sailedes blive et helt "mareridt". Hver gang, at der er et sving med en lille holdeplads, bremser Flensted op, farer ud af doren, hanker op i livremmen, der er tilbøjelig til at falde lidt ned, farer hen til skrænten, fotograferer og er pa vej tilbage med et gjaldende AFGANG, inden halvdelen af gymnasterne er nået ud af bilerne. Ikke usædvanligt karte holdene mellem 20-35.000 km på en turné, så det er forståeligt at mange af de lange døsige ture på highwayen, blev benyttet til en lille blund, dvs. med mindre man var på kørehold med Flensted, for det låklart iluften, at man var her også for at suge indtryk til sig, at tilegne sig viden og indsigt. Flensted mistede aldrig evnen til at lade sig begejstre.
Foråret 1977. Stedet er Philippinerne, nærmere betegnet øen Luzon. Vi er blevet roet ud til midten af en stor sø, hvor en kæmpe vulkan, Taal, rager op som en kejle. Den fine aske ligger flere hundrede meter ned af vulkanens sider. Varmen er uudholdelig. Sandet brænder gennem detynde skosåler. Målet er kanten af krateret, hvor man kan se ned på den boblende vulkan. Flensted er $i$ front med bar overkrop, den uundvarlige skuldertaske med papirer og penge er med, et lille lommetørklade dakker panden. Vi andre halser med. Flensted er 69 år gammel.

\section{Turneer og dagboger}

Fra 1939 og de følgende 50 år var Flensted ansvarlig for 14 store gymnastikturneer af et halvt til et års varighed samt 5 mindre ture af ca. en måneds varighed (jvf. Rejseoversigt). Den helt store rejseperiode var i tidsrummet 1961-1977, hvor ikke mindre end 10 store turneer blev gennemført. Alle gymnastikturneer har indtil 1977 haft det nordamerikanske kontinent som det væsentligste rejsemål, og ikke mindre end 6 af disse ture har inddraget flere andre verdensdele. Ud over 
15 opvisningsturneer i USA, 11 i Canada og 6 i Mexico har Flensted og Danish Gym Team besøgtikke mindreend 35 lande, heraf næsten halvdelen flere gange (jvf. Rejseoversigt) Den indtegnede rejserute fra turneen 1946-47 angiver et eksempel på en typisk rejserute rundt i USA med afstikkere til Canada, Mexico og Cuba.

Alle ture har haft sit særpræg, og alligevel er der en række fælles karakteristika, for eksempel rejseformen. Flensted ejede en flåde af ældre biler, der trak store trailere, som husede alle deltagerne. En væsentlig del af oplevelserne under opholdet i det amerikanske kontinent var denne specielle leveform, hvor man boede tæt sammen i grupper og planlagde sin køretur fra opvisningssted til opvisningssted $\mathrm{i}$ bedste cirkusstil - dette være sagt $i$ ordets mest positive betydning.

Når Danish Gym Team på visse ture rejste $\mathrm{i}$ andre verdensdele med indkvartering $\mathrm{i}$ alle kategorier af hoteller, blev den „amerikanske leveform" mindet af gymnasterne som noget særdeles attraktivt.

Et andet karakteristika var Flensteds iver for at holdet skulle opleve mest muligt af områdets kulturelle og naturmæssige seværdigheder. Når holdet efterhånden var blevet feteret i op til flere lande og havde mange måneders ind tryk bag sig, kunne det virke overvældende at fornemme Flensteds iver og begejstring, selvom han måske havde været selvsamme sted på hver eneste turné.

Der er ikke foretaget nogen statistik over antal opvisninger og tilskuertal for det samlede antal ture, men som eksempel kan nævnes sikre optegnelser for turneen 196364 , som viste, at holdet havde gennemført 165 opvisninger for ca. 225.000 tilskuere. Det samme store antal tilskuere blev tilsvarende anslået at have overværet holdet, der turnerede jorden rundt i 1976-77, men vel at mærke udelukkende ved opvisningerne i Østen. Det må derfor anses for at være et tal i underkanten, når det almindeligvis angives, at Flensted har været ansvarlig for ikke mindre end 2500 opvisninger for over 3 millioner tilskuere. Her er tale om opvisninger af den normale længde på ca. 2 timer, dvs. næsten 5000 timers gymnastik, hertil kommer hundredvis af små opvis- ninger af 20-30 minutters varighed præsenteret $\mathrm{i}$ andre sammenhænge, eksempelvis $\mathrm{i}$ forbindelse med sportsstævner, konferencer, verdensudstillinger etc. Det er heller ikke muligt at sætte tal på de mange TV-udsendelser, der er blevet udsendt overalt i verden.

Et ret ubeskrevet blad i forbindelse med alle Flensteds turneer har været de mange instruktionstimer i gymnastik, som instruktører og gymnaster i fællesskab forestod for primært idrætslærere og gymnastikinstruktører, men også for gymnastik-interesserede $i$ alle aldre. I forbindelse med turneen 197677 blev der gennemført workshops ved ca. hvert fjerde universitet eller college, der blev besøgt i USA, og under opholdet i Østen blev der afviklet op til flere workshops i følgende lande: Thailand, Singapore, Filippinerne, Japan og Korea.

De første ture er som nævnt udførligt beskrevet i bogform og film, men da den hektiske rejseperiode satte ind, blev de afløst af Lise og Flensteds rejsebreve til tidligere gymnaster.

Men størsteparten af de ca. 700 gymnaster, der i denne 50 års periode har rejst med Flensted, har på forskellig vis nedfældet de mange rejseindtryk i mere eller mindrestruktureret dagbogsform. Tilsammen udgør de en rigdom af oplevelser fra hele verden. I et enkelt tilfælde er en gymnasts dagbog om turen i 1970 blevet en gennemarbejdet bogudgivelse Drommerejsen - med FlenstedJensens gymnastikhold gennem USA - Canada Vestindien - Sydamerika 15).

\section{Rejselysten contra økonomi}

Flensteds rejselyst var større end hans økonomiske sans. De første ture kunne dårligt hænge sammen økonomisk. I flere tilfælde måtte Flensted sætte sit hus og sin livsforsikring i pant, når der skulle lånes penge til planlægning af en ny turné. Det var derfor en nødvendig startkapital, der blev oparbejdet, når de udtagne gymnaster skulle indbetale et rejsebeløb - i 1976-77 var dette beløb for eksempel 6.000,-kr - men på alle turene har gymnasterne fået det fulde beløb tilbage 
som lommepenge. I 60`erne oplevede Flensted pludselig en økonomisk vending, idet turneen 1963-64 gav et betydeligt overskud, der ville blive meget højt beskattet. I januar 1966 kunne man imidlertid læse i aviserne, at finansminister Henry Grünbaum havde fået følgende tekstanmærkning på finansloven:

Finansministeren bemyndiges til at frafalde krav om beskatning hos overlærer Erik Flensted-Jensen, Virum af den del af hans indkomst $i$ 1964, der er overfort til den selvejende institution „Den Internationale Danske Gymnastikhøjskole. Finansministeren motiveredesin ansøgning således:

Beslutningen vil medføre et engangsprovenuetab for staten på højst $140.000 \mathrm{kr}$. Beløbet er indtjent ved afholdelse af gymnastikturneer $i$ udlandet. Disse turneer, som må antages at have stor propagandamæssig værdi for Danmark, er hidtil drevet af hr. Flensted-Jensen personligt, men vil ifremtiden blive drevet af den på FlenstedJensens foranledning den 15. august 1965 oprettede selvejende institution kaldet "Den Internationale Danske Gymnastikhøjskole". De til institutionen overforte vardier består $i$ alt vasentligt af rekvisitter og materiel, herunder transportmateriel, der anvendes under turneerne. Vardien af det overførte materiel andrager højst $160.000 \mathrm{kr}$. En beskatning hos hr. Flensted-Jensen må antages at ville nødvendiggøre realisation - hel eller delvis - af det for turnévirksomhedens fortsattelse nodvendige materiel. 16)

Et typisk mønster for Flensteds følgende rejseliv har været, at givtige ture i USA er blevet efterfulgt af økonomisk drænende ture til andre verdensdele. Eventyret og rejselysten forblev den stærkeste kraft.

\section{Gymnastikturisme og fingeraftryk}

\section{Tilbageblik}

Aret er 1984. Jeg befinder mig med et hold danske gymnaster pån fargemellem de to New Zealandskeøer, Nordøen og Sydøen, da en lokal rejsende pludseligspørger: "Kenderdu Flensted-Jensen?" Han var larer og fortalte begejstret om en opvisning, han havde set $i$ midten af 60'erne, og om hvordan det havde inspireret ham i undervisningen.

Året er 1993. Jeg befinder mig i Mexico med et hold unge drengegymnaster. Da vi ankommer til en stor privat gymnastikskole kikker vi forundret på de mange kendte gymnastikbilleder af Flenstedgymnaster. Lederen af skolen fortæller, at han havde varet involveret $i$ Danish Gym Teams besøg i 1975. Resultatet af besøget havde været, at skolen siden da havde lagt vægt på holdgymnastik for alle aldre.

\section{Angreb på Flensteds rejser}

I mellemkrigs- og i efterkrigstiden var det hovedsaglig tre gymnastikledere, der bragte de unge gymnaster ud over landets grænser: Niels Bukh - og senere Arne Mortensen - med udtagne elever fra Gymnastikhøjskolen iOllerup, Kristian Krogshede med udtagne elever fra Gerlev Idrætshøjskole og Erik Flensted Jensen med udtagne gymnaster fra landets gymnastikforeninger 17).

Denne rejseform blev af kritikere ofte betegnet som gymnastikturisme. Begrebet gymnastikturisme har bidt sig fast hos kritikere, også hos forfatteren af denne biografi, der offentligt har kritiseret nutidens rejseri i de situationer, hvor rejsen ikke har haft andet bærende værdigrundlag, end at man blot skulle ud - og helst langt væk. Dette manglende værdigrundlag kan ikke lastes de ovennævnte gymnastikledere, så der må have foreligget andre væsentlige grunde til den rejste kritik.

Den 10. december 1948 bragte Kristeligt Dagblad nogle uddrag af en artikel i Dansk Idræts Forbunds officielle meddelelser, skrevet af gymnastiklærer Marius Lefévre, som heri angreb gymnastikturismen. Dette fik Kristian Krogshede til at skrive følgende i Kristeligt Dagblad om angrebet på Flensted:

Kunne det ikke trenkes, at Flensted har ret, når han siger, at han med sin turnéville gavne de unge og tjene en menneskelig og kristelig opgave? Og at Lefévre har uret når han insinuerer, at Flensted kun var ude på at tjene penge? At der meldte sig uventede vanskeligheder, og der blev begået fejlgreb er aldrig blevet benægtet, men mon ikke de unge som var med på turen og som nu siger god for Flensted, har ret? Jeg tror det, og 
Alle forhold taget $i$ betragtning er jeg ikke i tvivl om, at Flensted-Jensen under sine tidligere turneer har gjort Danmarkære. Jeg mener, at opvisningerne har varet til positiv gavn for vort lands anseelse $i$ USA, og jeg skal tillade mig at henstille, at der fra myndighedernes side ydes han bedst mulig stotte $i$ hans betræbelser for at gennemføre den planlagte turné.

\section{Kollision på hjemmebanen}

Holdningen i Dansk Gymnastik Forbund til Flensteds rejsevirksomhed var i perioder meget kritisk og negativ. Set i bakspejlet kan det derfor forundre, at såvel formanden for Dansk Idræts-Forbund, general H.F. Castenschiold og formanden for Dansk Gymnastik Forbund, oberst F.O Jørgensen sad i Præsidiet for Flensteds første gymnastikturné i 1939.

De tydeligste kollisionsområder var for det første diskussionen om amatørstatus contra professionel status, hvilket resulterede $i$, at flere konkurrencegymnaster, eksempelvis Elkana Grønne, Niels Erik Bertelsen, Lisbeth de Blanc og Arne Thomsen, der havde valgt at deltage på en Flenstedturné, blev sat i karantæne i 3 år af Dansk Gymnastik Forbund. Til trods for at Flensteds Danish Gym Team (DGF) aldrig deltog i nogen konkurrence eller fik udbetalt løn som gymnaster udover værdien af kost og rejse, blev opfattelsen af denne professionelle status fastholdt ind til de sidste turneer i 70'erne. I en portrætudsendelse om Erik Flensted-Jensen i DR-TV giver en af de berørte gymnaster, Niels Erik Bertelsen, udtryk for, at han oplevede det som nogle forkvaklede regler 20).

For det andet var det magtpåliggende for DGF, at markere det principielle i, at qua medlemsskabet af Federation Internationale de Gymnastique (FIG) var det efter forbundets opfattelse DGF, der skulle bestemme hvem og hvor, man måtte rejse, såfremt arrangementet indebar et samarbejde med andre gymnastikforbund - dette var også holdningen, selv om forbundet ikke havde noget hold af lignende karakter, der kunne træde i stedet. Det var med andre ord mere princippet om retten til at bestemme, på baggrund af artikel 9 i FIG's regler, end en positiv holdning til formidling af en dansk gymnastiktradition samt manglende forståelse for gymnasternes tarv, der her havde muligheden for at opleve og leve op til egne og andres gymnastiske forventninger.

Denne monopolitiske holdning har ofte forundret ambassadefolk, når de har arbejdet for at fremme udveksling og reklame for dansk gymnastik i almindelighed. I USA var denne holdning ikke noget specielt problem, idet de primære samarbejdspartnere for Flensted var universiteter og colleges, men i mange andre lande, især i Østen og Sydamerika, var det naturligt for såvel universiteter som ministerier at inddrage det respektive gymnastikforbund, idet der i disse lande er en stærk statslig styring af idrætten og derfor kun ét forbund. Dette har i forskellige situationer givet større eller mindre problemer, eksempelvis forsøgte Flensted at organisere en tur til Japan i foråret 1967, hvilket resulterede i følgende notat fra ambassadens møde med det japanske gymnastikforbund:

Det japanske forbund havde imidlertid fået betrenkeligheder ved at stå som sponsor for det danske gymnastikhold, idet man havde varet udsat for kritik under moder i det internationale gymnastikforbund af, at man havde støttet og arrangeret såvel turneringer som opvisninger af udenlandske hold, der ikke var anerkendt af det pågxldendelands gymnastikforbund. Man måtte derfor, forinden yderligere kunne foretages isagen, anmode om snarest belejligt at modtage en officiel skrivelsefra det danske gymnastikforbund, hvori dette gav udtryk for, at det intet havde imod, at det japanske gymnastikforbund arrangerede og understottede Flensted-Jensens gymnastikhold $i$ Japan, og at man ikke senere fra dansk side ville kritisere en sådan japansk indsats $i$ det internationale gymnastikforbund. Endvidere ville man satte pris på at modtage garanti for, at de almindelige amatørregler ikke blev overtrådt af holdets medlemmer ved deltagelse i en sådan turne.

Turen til Japan blev ikke til noget i denne omgang. Af referatet fra mødet fremstår følgende tankevækkende holdning til måden, hvorpå man fremmer gymnastikinteresse:

Man lagde ikke skjul på, at man mente, dei danskegymnastikhold kunne bruges til at fremme 
interessen bland den japanske ungdom for gymnastik, idet man havde gjort den erfaring, at opvisning af de japanske verdensmestre rundt om i landet mere havde skræmt folk end egentlig gjort dem interesseret $i$ gymnastik, fordi den almindelige japanske unge mand eller kvinde meget vel kunne indse, at det ville tage år, hvis det overhovedet kunne lykkes at nå op på en standard som disse japanske gymnaster, idet man forbandt al gymnastik med topgymnastik. I 1973 støder Flensted ind i to tilsvarende reaktioner. I et brev fra det indiske gymnastikforbund afslår forbundet et samarbejde 22), medmindre DGF anbefaler besøget, og ved en senere lejlighed - da Flensted via den danske ambassade i Peking var inviteret til en 19 dages turnè i Kina i foråret 1973, som det første danske gymnastikhold (såvidt vides det første idrætshold fra den vestlige verden bortset fra de amerikanske bordtennisspillere, der havde været der sammen med præsident Nixon) - kunne den samme situation have forekommet, hvis ikke daværende ambassadør Paludan havde talt Flensteds sag over for det kinesiske idrætsforbund.

Selv om Flensted inderst inde må have været skuffet over den holdning, der mødte ham, henholdsvis fra kredse i DGF, men også i perioder fra den Gymnastikhøjskole, der reelt havde lagt fundamentet for hans livsgerning, viste Flensted almindeligvis ikke gymnasterne, at det gik ham på eller at det irriterede ham. Han tog det til sig uden at kaste sig ud i en åben aggressiv eller forsvarende brevudveksling.

\section{Formidling af dansk kultur}

Turen i 1946-47 skabte fundamentet for de kommende tures succes. Fra ukendt status blev netop dette hold inddraget $i$ datidens medieverden. Holdet blev det første gymnastikhold i verden, der blev udsendt i fjernsyn efter optagelser i New York af National Broadcasting Company, og filmselskabet Paramount fulgte senere efter med optagelser til „ugerevuen", der blev udsendt over hele verden. Alene i USA blev det af den danske ambassade anslået, at denne udsendelse blev set af 35 mill.
En af opvisningerne i Washington blev overværet af dr. Frank Stafford, der i det amerikanske undervisningsministerium havdeen stilling svarende til en daværende gymnastikinspektør. I et brev til Flensted skriver han følgende: ",

Fredag den 24. januar havde jeg den fornøjelse at se Danish Gym Teami gymnastiksalen på Hyattsville High School. Det var mig en stor glæde at overvære denne fortræffelige demonstration af legemlig opdragelse. Jeg er overbevist om, at De og Deres hold i hojere grad vil stimulere interessen for fysisk opdragelse her i landet og bidrage meget til at forbedre vore metoder. Det glader mig overordentligt, at det har været muligt for Dem at komme til Staterne og vise Deres idrætsfolks dygtighed for det amerikanske publikum. Jeg er sikker på, at sådanne opvisninger medvirker stærkt til at skabe en bedre forståelse mellem vore to folk. 23)

Flensted opnåede på samme tur at få lavet en 3-siders billedreportage til såvel den amerikanske som den internationale udgave af "LIFE" 24). Det blev en ubetalelig reklame, der blev udsendt i over 5 mill. eksemplarer over hele verden.

I de følgende 30 år blev det dagligdag for Flensted, at der var opmærksomhed på Danish Gym Team's opvisninger fra pressen overalt i verden samt radiointerviews af ledere og gymnaster. Efterhånden som TVmediet voksede blev dèt den naturlige formidler af reklame for holdet, men også direkte udsendelser fra opvisningerne blev mere almindeligt.

Flensteds ture skabte ikke kun opmærksomhed omkring den danske gymnastikkultur, men inspirerede også flere amerikanske universiteter og colleges til at ansætte danske undervisere i gymnastik. På baggrund af Danish Gym Team's besøg i Korea i 1977, som det første hold siden Flensted havde været der som gymnast i 1931, ansøgte det koreanske undervisningsministerium DANIDA om støtte til at få en dansk gymnnastiklærer til Korea. Resultatet blev, at lederen af Danish Gym Team 1976-77 blev udsendt som underviser på koreanske universiteter i en 2-års periode 1978-80. 


\section{Anerkendelse af gymnastikarbejdet}

Igennem årene har Flensted modtaget utallige takkeskrivelser og anerkendende ord for den inspiration, der er blevet formidlet ved de anslåede 2500 opvisninger, til den gymnastiske udvikling, til den fysiske træning i almindelighed og ikke mindst til en positiv mellemfolkelig forståelse.

Følgende citater giver et billede af de mange udsagn:

...the Danish troupe contributed significantly to Danish-American understanding and an appreciation of common values in the realm of citizenship and sportsmanship".

William McC. Blair, Ambassador,

American Embassy, Copenhagen 25) I believe that you will find that the Danish Gym Team would prove to be one of the finest attractions that you have ever sponsored. On the second occasion that I saw this group perform, I was at the National Convention of the American Association for Health, Physical Education and Recreation in Cincinnati. There was a standing ovation for them for about five minutes.

Ross Allen, Director of Education, State

University, Cortland, New York 26) I could not have imagined the tremendous effect of that performance upon the children and the adoults in our school system. Since the conclusion of your performance here on March 20, 1969, we have received innumerable telephone calls and letters from principals, teachers, and parents concerning your team's awe-inspiring performance.

Jayne A. Meyer, Supervisor, Health and Physical Education, Tuscaloosa County Board of Education, Alabama 27)

En hel speciel anerkendelse for sit arbejde med at vise dansk gymnastik opnåede Flensted i forbindelse med de Olympiske Lege i Mexico 1968. Danish Gym Team blev her udsat for den største opmærksomhed fra verdensmedierne, der nogensinde er blevet den danske holdgymnastik til del, idet Flensted var blevet inviteret til at vise en del af sit program under afslutningsceremonien for 100.000 tilskuere og TV-seere over hele ver- den - og mærkelig nok blev netop dette indslag ikke sendt $\mathrm{i}$ dansk TV.

Flensted havde med stor succes deltaget $\mathrm{i}$ en stor folklorefestival i forbindelse med de Olympiske Lege. Koordinatoren af festivalen skriver således:

I consider that the participation of your group added greatly to the splendor of the Festival and that your artists left to Mexico and to her people the most outstanding expressions of your country: your exquisite art, your dances. The Folklore of Denmark could not havesent a better representative to this artistic event than the Danish Gym Team, which you so competently directed." 28) Det var på den baggrund, at Flensted blev inviteret til at indgå i afslutningsceremonien, som det eneste udenlandske hold. Under overskriften „Danske Gymnaster vakte jubel ved afslutningen af olympiaden Mexico 68" skrev Munk Jensen fra BT følgende:

Optakten til finalen blev et overraskende dansk indslag, som henrev de hundrede tusinde tilskuere til begejstring og indirekte gav Danmark endnu en guldmedalje ved disse forunderlige lege. 29)

\section{Drivkraften bag personligheden}

\section{Tilbageblik}

Verdensturneen 1976-77. Den daglige morgensamling blev stedet, hvor vi som deltagere $i$ gymnastikturneen blev gjort bekendt med Flensteds kristne opdragelse $i$ Vordingborg, hans tid som gymnast hos Niels Bukh, hans tid som lærer, hans agteskab med Lise og ikke mindst fortællingerne om de tidligere gymnastikturneer med alle planlagningsproblemerne, der kun blev overvundet ved en tillid til, at Gud ville hjælpe ham til at finde den rette løsning. Morgensamlingen blev ogsåstedet, hvor vi blev introduceret til Flensteds opfattelse af englevagt. Der var ikke en morgenbøn uden Flensted bad om englevagt om sine gymnaster. Det var ikke umiddelbart ord eller en holdning, som de fleste af os var bekendt med og som vi $i$ vores usikkerhed ofte reagerede imod, men $d y b t i$ vore sind lå alligevel erkendelsen af det usadvanlige $i$, at mange farlige handelser 


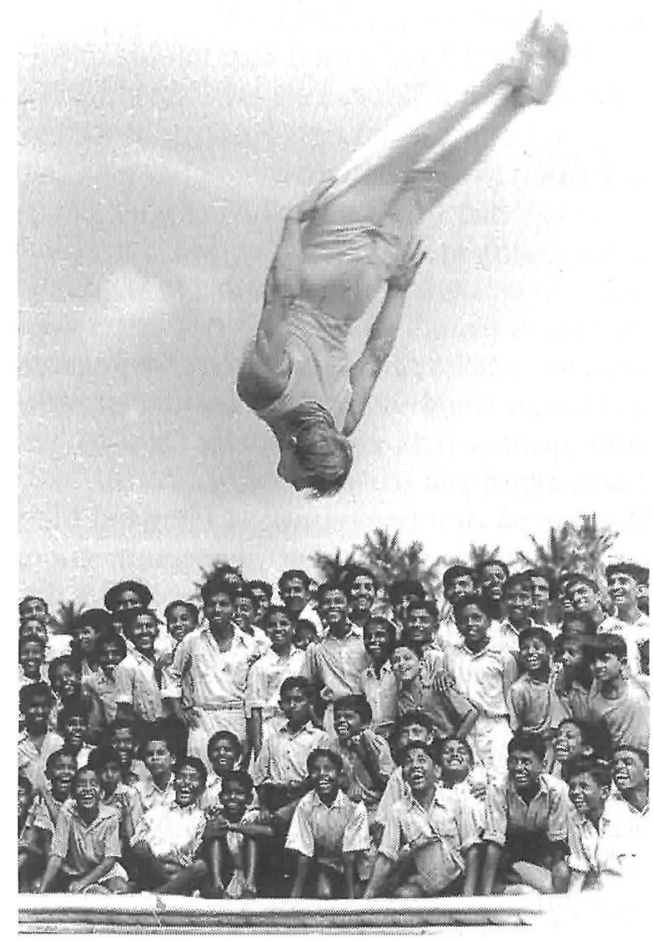

De danske gymnasters artistiske kunnen har vakt begejstring overalt i verden. Her svaver en salto over Ceylons jord.

gennem et mangeårigt rejseliv var klaret uden problemer.

\section{Den kristne tro}

Drivkraften i Flensteds liv var hans kristne tro. Alle der kom i forbindelse med Flensted blev konfronteret med denne tro.

Anne Marie Lind Børup skriver i forordet til bogen Med dansk ungdom til Amerikas brogede verden om sit samarbejde med Flensted:

Det var ikke altid, jeg kunne folge ham, forstå hans tankegang og dispositioner; men det svakkede aldrig styrken $i$ vort samarbejde, som byggede på ubetinget gensidig tillid." 30 )

At denne bog, som alle andre senere bøger forfattet af Flensted, er præget af et kristent livssyn falder helt naturligt. Anne Marie Lind Børup skriver således i samme forord:

For os, der kender ham, ville der vare et tomrum i den, hvis dette ikke var med. At vidne om sin tro er et krav, som hans samvittighed stiller ham, og dette krav kan han slet ikke komme uden om. Vi forstod ham på dette punkt og larte at respektere det, så det absolut foltes som et naturligt islat ivor dagligdag, noget, som vi ikke ville undware.

\section{En skelsættende begivenhed}

Flensted var vokset op i et kristent folkekirkeligt miljø, men en skelsættende oplevelse i 1935 ændrede Flensteds kristne holdning. Sammen med sin bror deltog han i et kristent nordisk sommermøde for 500 unge ved den norske by Gjövik under ledelse af kendte kristne forkyndere bl.a. professor Hallesby fra Norge og den senere biskop Kaj Jensen fra Danmark 31). Flensted blev ved dette møde overbevist om, at Guds ord, som de står i Bibelen, var den klippegrund han skulle bygge sit liv på uden at sætte spørgsmålstegn.

Her ligger også årsagen til, at Flensted som voksen ikke var medlem af Folkekirken til trods for, at han gerne ville have vedblivet at være medlem af denne, således at han fortsat kunne medvirke ved børnegudstjenester i Hellerup Kirke og varetage sin religionsundervisning. Flensteds syn på dåben var, at det var en bekendelsesdåb, man selv vælger, når man er kommet til en personlig overbevisning om sin tro på Jesus. Hvis man som voksen lader sig gendøbe efter denne opfattelse, er man imidlertid ikke længere medlem af Folkekirken. Denne konsekvens berørte Flensted på en helt usæd vanlig måde, idet kong Christian X. måtte sige nej til også at være protektor for Flensteds anden tur med henvisning til Flensteds manglende medlemsskab af Folkekirken 32), idet Flensted i sin anmodning til kongen havde skrevet, at han ville drive turen $i$ en kristen ånd med undervisning i kristendomsforståelse.

Flensted knyttede sig til forskellige frikirkelige menigheder bl.a. Kristent Fællesskab, der ikke direkte er en menighed, men et forum for et kristent fælleskab uanset ens frikirkelige tilknytning.

Mødet i Gjövik understregede også for Flensted vigtigheden af, at man også var 
rede til at fortælle andre om, hvad Jesus betød for én.

Gymnaster og instruktører udtaget til Flensteds gymnastikturneer vidste eller blev gjort bekendt med, at alle opvisninger ville blive afsluttet med hans personlige kristne vidnesbyrd, og at hver dag ville blive indledt med fælles morgensang og -bøn. Hvis ens personlige holdning eller tro ikke kunne acceptere disse forhold, skulle man ikke vælge at deltage.

Morgensangen og -bønnen har sikkert ændret form fra det første hold i 1939 til eksempelvis turneen 1976-77, der blev den sidste „års-turne", men på alle hold har der været ført diskussioner gymnasterne imellem om indhold, form og oplevelsesgraden af missionerende adfærd.

I sin bog Drømmerejsen omtaler gymnasten Arne Thomsen en situation fra en opvisning i 1970 i Mendoza, Argentina, hvor Flensted på sin sædvanlige form giver udtryk for sin kristne holdning:

Under hujen, skrigen og lange klapsalver ruller vi måtten sammen og stiller op til udmarch. Det ser en overgang ud til, at betjentene har vanskeligt ved at holde ro og orden. Publikum synes at vare i ekstase. De fleste har rejst sig og klapper som vilde eller svinger hatten, hvis de har en saidan. Mange prover at mase ned mod de forreste rakker for at komme os på nært hold, eller for at vare klar med autografbogerne. Der bliver pludselig slående ro, da Flensted griber mikrofonen foran os 24 gymnaster og vore 2 ledere, der står opstillet på en snorlige række med svedperler haglende ned over de af solen opvarmede og ildrøde kinder. Med høj og frejdig røst siger Flensted tak for en festlig dag og giver udtryk for sin personlige påskønnelse og tro på Gud samt en overbevisende strerk mening om Jesus Kristus som verdens frelser og eneste håb. Påny ser vi noget, som for os virker helt ualmindeligt sydamerikanernes overmåde, taknemmelige begejstring for disse starke ord. At se 20.000 mennesker her i Mendoza stå op og give et flere minutter langt bifald efter Flensteds ord, fär det virkelig til at gibbe i én. Han er af mange blevet kritiseret for det, men af endnu flere rost til skyerne. Bl.a. kommer en dansk farmer hen til ham, slår ham på skulderen med en overvoksen næveog siger: ,Det var fan'megodt med deord!'.33)

\section{En pågående trosholdning.}

Flensteds overbeviste tro hjalp ham gennem personlige kriser og gav ham mod til beslutninger, som de fleste andre ville have undladt især efter rationelle økonomiske overvejelser. Til gengæld har Flensteds tro også bevirket, at mange i 50'erne og 60'erne, for eksempel idrætsforbund, højskoler og bevilgende myndigheder, reagerede med en vis modstand på denne synlige sammenblanding af en kristen holdning og et ungdomsarbejde. I Danmark har der altid været en tendens til, at tro var noget personligt, som man ikke luftede uden for kirkens vægge.

I TV-portrætudsendelsen om Flensted svarer han til spørgsmålet om, hvad der har været hans største skuffelse, at: Jeg måske nok havde ventet, at flere af gymnasterne ville folge min tro. Årsagen var måske, at mange opfattede Flensteds form som for pågående. Der var ikke rum for den enkeltes egen rolige udvikling og stillingtagen - selvom det reelt var det, som Flensted ønskede.

\section{Ubeslutsomhed og målrettethed}

Flensted angiver flere gange i sine bøger, at han er ubeslutsom, men det er kun, indtil han har truffet sin beslutning. De af os, der har været tæt på Flensted og derfor ofte er blevet spurgt til råds, har ofte måttet sande, at det bedste tidspunkt for at lufte sin mening var i Flensteds ubeslutsomme fase. Var beslutningen taget af Flensted, kunne man tydeligt mærke, at det ikke faldt i god jord, hvis ens mening ikke var samstemmende med den trufne beslutning.

Ubeslutsomheden blev fulgt af en målrettethed og ofte kreative veje til at fremme det valgte mål eller beslutning.

Oplevede Flensted en offentlig og for ham negativ holdning til religiøse emner, der lå ham stærkt på sinde, reagerede han kraftigt og spontant med mere end blot et tilfældigt læserbrev. Dette står i stor kontrast til reaktionen på personlige angreb på Flensteds rejsevirksomhed, hvilket aldrig fremkaldte en tilsvarende angrebslyst eller forsvarsposition. 
I august 1973 reagerede Flensted således med et „Åbent brev til Danmarks Regering og Folketing" 34), på baggrund af sagen om Thorsens Jesus-film og sammenhængen med folketingets daværende behandling af lovforslaget om blasfemiparagraffens ophævelse. Flensted opfattede det som en skændsel og utilgiveligt, at Danmark ville ødelægge sit omdømme i udlandet ved officielt at støtte en blasfemisk Jesus-film. Næsten 10 år senere udsender Flensted i 1982 et nyt 4sider åbent brev „Efterlysning: Ny værdighed i den vestlige verden“ 35). Denne gang er det verdensopinionens fordømmende holdning til situationen i Israel, der får Flensted til at reagere. Brevet udsendes til regering, folketing, til alle danske ambassader, til DR og alle dagblade. I en engelsk udgave sendes brevet til FN's hovedkvarter, til alle de tilknyttedelandes FN-ambassadører samt til PLO. Endvidere sendes brevet til alle ambassader i Israel og til større engelsksprogede aviser. Den engelske udgave af brevet blev alene udsendt i 5.000 eksemplarer.

\section{Idémageren Flensted}

TV-udsendelsen „Flik-flak Flensted “36) fra 1987, der var en portrætudsendelse om Erik Flensted-Jensen, indledes bl.a. med: „Nu er Flensted 77 år og faldet til ro i Virum" - og sjældent har man taget så meget fejl. Flensted kunne ikke falde til ro. Til det sidste tumlede han med planer om nye rejseudfordringer. Den sidst gennemførte tur til Vestindien og Puerto Rico i 1989 tog imidlertid så meget på den 81 åriges kræfter, at Flensteds jævnaldrende kone Karen, som han kort efter Lises død havde giftet sig med i 1978, forsøgte at tale ham fra yderligere gymnastikture i de følgende år, men kun få måneder før sin død vurderede Flensted stadig muligheden for at organisere en ny tur til Chile.

Flensted arbejdede hele sit liv med nye ideer, nye rejsemål og nye udfordringer. Ud over gymnastikturneernes mange destinationer forsøgte Flensted således i mange år at oprette en kristen ungdomsskole, der skulle rejse ud i verden. En anden drøm om at samle et udtaget gymnastikhold på nordisk plan blev heller ikke en realitet, men på visse hold var der en enkelt gymnast fra de andre nordiske lande. Et af de mest gennemarbejdede projekter var oprettelsen af the International Floating Academy for Physical Education and Recreation i 1967 37). Hensigten var at organisere internationale uddannelses krydstogter, som en form for rejsende højskole med faste undervisningsforløb i fagområder, der var relevante i forhold til de lande, der skulle besøges på togtet. Målgruppen var primært amerikanske studerende og med Danish Gym Team som en aktiv deltager i de 45 til 90 dages planlagte krydstogter, idet holdetskullegive opvisninger i de lande, hvor skibet lagde til. En invitationsskrivelse til amerikanske universiteter gav dog ikke tilstrækkelig baggrund for at kaste sig ud i dette eventyr.

Til gengæld gav Flensted mange unge gymnaster et eventyr. Den dag i dag samles gymnasterne fra de respektive hold helt tilbage fra Amerika-drengene i 1939 og trods tidens tand, bliver hændelser og oplevelser trukket frem, diskuteret og kommenteret. Ingen er gået upåvirket ud af rejsen med Flensted.

Ved det afsluttende frokostbord på hotel „Brasilia" ved Odense, mærker man for alvor det sammenhold og fantastiske kammeratskab, der efterhånden har udviklet sig på holdet. Vel har der af og til været uoverensstemmelser på rejsen, men de synes $i$ denne sidste afskedsstund som blast bort af stærke venskabsbaind. Flensted er denne aften i et helt overstadigt god thumør. Man synes at kunne mærke, at han på en måde føler sig løst fra det kxmpemæssige ansvar, han bxrer ved at rejse med så mange unge mennesker..... Ind imellem talerne bliver der bådesnakket om fremtidens planer samt om de forgangne spændende måneder. Det er ikke så lidt man har varet igennem sammen: Eventyrlige oplevelser og $i$ mindre grad skuffelser - der er til tider arbejdet hårdt, men ind imellem har der også varet tid til ferie - mange tårer er blevet udgydt, men endnu flere gange er der blevet leet, pjanket og festet til den store guldmedalje - man har frosset, og man har svedt, så „kiloerne" ligefrem løb af kroppen- 
man er blevet kritiseret, og man har fået ros-man har oplevet vrede, jalouxi og misundelse, men også sammenhold, hensyn og ansvar - kort sagt, der er blevet spillet på de fleste af livets strenge".

Arne Thomsen, „Drømmerejsen“ 38)

\section{REJSEOVERSIGT}

Erik Flensted Jensens rejser som gymnast i perioden 1925 - 1931:

Med Niels Buhk i Tyskland og Tjekkoslovakiet, efteråret 1925

Med Niels Buhk til Island, Tyskland, Holland, England og Skotland, efteråret 1927.

Med Niels Buhk til Tyskland, Østrig og Ungarn, foråret 1930

Med Niels Buhk jorden rundt, 1931.

Erik Flensted Jensens gymnastikturneer i perioden 1939 - 1989

1939: Gymnastikturne til Amerika med drengehold. Instruktør: Erik Flensted-Jensen

1946-47: Gymnastikturne til Amerika. Instruktør: Erik Flensted-Jensen, Signe Bertelsen, Anne Marie Lind Børup. Pianist: Thorkild Tromholt-Madsen

1949-50: Gymnastikturne til Amerika og Mexico. Instruktør: Erik Flensted-Jensen, Kirsten Stampe Andersen. Pianist: Gunnar Engberg Hansen

1954-55: Gymnastikturne jorden rundt. Instruktør: Erik Flensted-Jensen, Nina Swartz, Inger Riis Laursen (folkedans). Pianist: Esther Karottki

1961-62: Gymnastikturne til Grækenland og Amerika. Instruktør: Gunnar Michael Andersen, Aase Nielsen. Pianist: Astrid Hartvig

1963-64: Gymnastikturne til USA og Canada. Instruktør: Jørgen Flensted Jensen, Kirsten Tyrsted Rasmussen. Pianist: Ernst Rasmussen

1965-66: Gymnastikturne jorden rundt. Instruktør: Svend Jørgensen, Else Petersen. Pianist: Esther Jørgensen

1967-68: Gymnastikturne til USA, Canada og Mexico. Instruktør: Henning Petersen, Astrid Hartvig. Pianist: Willy Bertelsen, Astrid Hartvig
1968-69: Olympiadeholdet til USA, Mexico og Mellemamerika. Instruktør: Jørgen og Kirsten Flensted Jensen. Pianist: Jutta Nielsen, Hans Peter Larsen

1970: Gymnastikturne til USA, Canada, Vestindien og Sydamerika. Instruktør: Jørn Josefsen, Helia Bom. Pianist: Inger Lise Julin Andersen

1971: Gymnastikturne til USA og Canada. Instruktør: Poul Burgård, Jytte Brandtoft, Else Faurschou Schmidt. Pianist: Lone Hansen

1972-73: Gymnastikturne til USA og det fjerne $\emptyset$ sten. Instruktør: Knud Bjørn, Lis Ejersbo. Pianist: Inger Lise Julin Andersen, Vagn Birk Jensen

1974-75: Gymnastikturne til USA og Mexico. Instruktør: Poul Christensen, Birgit Boysen. Pianist: Anders Kragh Jespersen

1976-77: Gymnastikturne til USA og det fjerne $\emptyset$ sten. Instruktør: Finn Berggren, Birgit Boysen. Pianist: Vagn Birk Jensen

\section{Folgende er korte ture af op til en måneds} varighed:

Hawaii, marts 1979, med Holstebro. Repræsentationshold

Thailand, oktober 1980, med Helsinge-gymnasterne

Malaysia, februar 1981, med Holstebro Repræsentationshold

USA, oktober 1981, med Ringsted-drengene og Glums $\emptyset$-pigerne

Vestindien, januar 1989, med Ringsted-drengene og Glums $\varnothing$-pigerne

\section{Danish Gym Team har givet opvisninger i} folgende lande:

(lande, der er besøgt undervejs uden opvisninger, er ikke medregnet)

USA (15 gange)

Canada (11 gange)

Mexico (6 gange)

Thailand (4 gange)

Bahama øerne (3 gange)

Følgende 9 lande er alle besøgt 2 gange:

New Zealand, Australien, Fiji, Filippinerne, Malaysia, De Vestindiske Øer, Puerto Rico, Singapore, Hong Kong. 


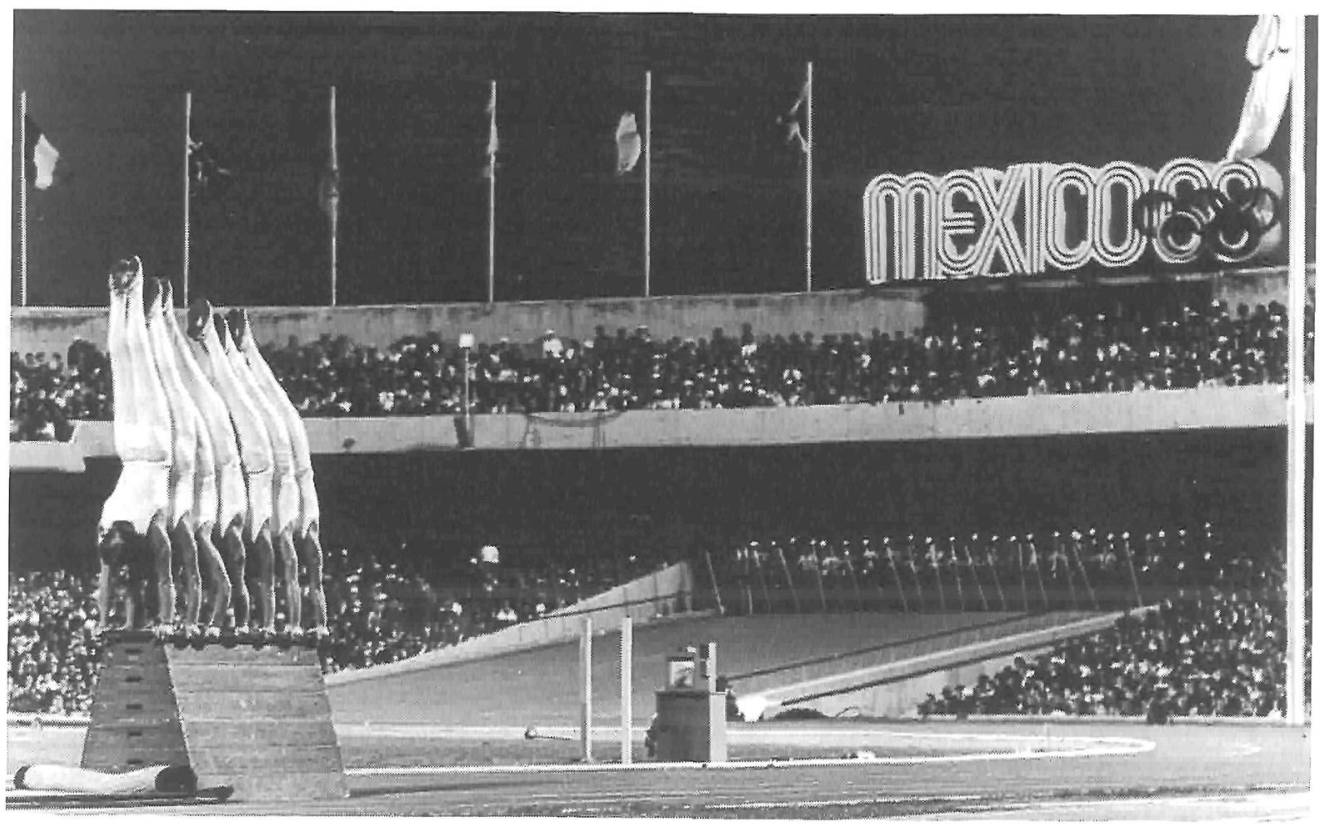

Et af Danish Gym Teams højdepunkter under afslutningsceremonien ved de Olympiske Lege $i$ Mexico 1968.

Følgende 24 lande er besøgt en enkelt gang: Cuba, Tahiti, Ceylon, Grækenland, Indien, Pakistan, Israel, Guatemala, El Salvador, Martinique, Barbados, Surinam, Brasilien, Uruquay, Argentina, Chile, Peru, Equador, Colombia, Venezuela, Indonesien, Kina, Japan, Korea

\section{Noter:}

1) I følgende uddrag af Niels Bukhs brev til eleverne 1924 citeret fra Kristian Krogshede Mirl der fra Ollerup og Gerlev, omtales det udtagede mandlige gymnastikhold, der skulle vise primitiv gymnastik ved Olympiaden i Paris, juli 1924: Jeg er De Danske Skytte- og Gymnastikforeninger meget taknemmelig, fordi de overlod mig opgaven at reprasentere Danmark med gymnastik, skønt jeg kun ville gøre det uden for konkurrence og jeg var glad ved at erfare, at vor primitive grundgymnastik nu er nået så langt frem, at landet og denne store forening ville lade sig reprasentere ved vor gymnastik. p.109.

2) Krogshede, K.: Minder Fra Ollerup og Gerlev - en bondedrengs livseventyr, Delta, 1980, p.122.

3) Flensted-Jensen, Erik: Med Niels Bukh Jorden Rundt, Gyldendalske Boghandel Nordiske Forlag, 1932, p. 14.
4) Flensted Jensen, Erik: Med Niels Bukh Jorden Rundt, Gyldendalske Boghandel Nordiske Forlag, 1932, pp. 86-87

5) Flensted-Jensen, Erik: Med Niels Bukh jorden rundt, Gyldendalske Boghandel - Nordisk Forlag, 1932

6) Brev til lærerErik Flensted-Jensen, dateret Gymnastikhøjskolen i Ollerup, den 6.5. 1932

7) Flensted-Jensen, Erik: 40.000 kilometer under Dannebrog - Med Amerika-Drengene til Vestindien, USA og Canada, Flensted-Jensens Rejsefond, København, 1945

8) Brev fra H. M. Kong Christian X.'s Kabinetsekretær, KammerherreG. Bardenfleth, Amalienborg, den 31. Juli 1944.

9) Flensted-Jensen, Erik: Med dansk Ungdomi Amerikas brogede verden - En gymnastikturnè til USA, Canada og Cuba, Flensted-Jensens Rejsefond, København, 1952

10) Flensted-Jensen, Erik: Mit livog mine rejser, eget forlag, København, 1983

11) Flensted Jensen, Erik: Med dansk ungdom $i$ Amerikas brogedeverden, Flensted-Jensens Rejsefond, 1952, p.97

12) Flensted-Jensen, Erik: Mit livogmine rejser, eget forlag, Kobenhavn, 1983, p. 68

13) Bukh-opvisningen igår. Fyns Stiftstidende, 23. oktober 1933

14) Flensted-Jensen, Erik: Med dansk Ungdom i Amerikas brogede verden - En gymnastikturnè til USA, Canada og Cuba, Flensted-Jensens Rejsefond, København, 1952, pp. 5-6 
15) Thomsen, Arne: Drommerejen - med FlenstedJensens gymnastikhold gennem USA - Canada Vestindien - Sydamerika, Esbjerg, 1971

16) Skattefrihed til en kendt gymnastik-turnéleder, Berlingske Aftenavis, 24 januar 1966

17) Gymnaster, der deltager i internationale gymnastikkonkurrencer, inddragesikkeidenne sammenhæng

18) Krogshede, K.: Minder Fra Ollerup og Gerlev - en bondedrengs livseventyr, Delta, 1980, p. 372

19) Ambassadør Henrik Kaufmans indberetning til Udenrigsministeriet, den 3. marts 1949, g: $667 / 54$

20) DR TV-sporten, portræutudsendelse, Flik-flak Flensted, producer Hans Gronfelt, 1987

21) Brev af 4. marts 1966, J.nr. 42.U.10, Den Danske Ambassade, Tokyo

22) Brev til Erik Flensted-Jensen fra President Rameshwar Dayal, Gymnastic Federation of India, den 25. januar 1973, journal nr. GFI/73/ 7-677

23.) Erik Flensted Jensen, Erik: Med dansk ungdom $i$ Amerikas brogedeverden, Flensted-Jensens Rejsefond, 1952, p.51

24) LIFE, International Edition, March 15, 1948,pp. $33-35$

25) Citeret fra en anbefalelsesskrivelse fra Ambassadør William McC. Blair, American Embassy, Copenhagen, October 4, 1962

26) Citeret fra et brev af 10 december, 1962, til Richard J. Williams, Chairman, Youth Fitness Committee, Rochester 4, New York fra Ross Allen, Director of Education, State University, Cortland, New York

27) Citeret fra brev af Jayne A. Meyer, Supervisor, Health and Physical Education, Tuscaloosa County Board of Education, Alabama, March 26, 1969
28) Officielt tilsendt dokument fra Ana Merida, Coordinator, World Folklore Festival, Comite Organizador De Los Juegos De La XIXOlimpia, 19. November 1968

29) Munk Jensen, Danske gymnaster vakte jubel ved afslutningen af olympiaden, BT, mandag den 28 oktober 1968

30) Flensted-Jensen, Erik:Med dansk Ungdomi Amerikas brogede verden - En gymnastikturnè til USA, Canada og Cuba, Flensted-Jensens Rejsefond, Kobenhavn, 1952, p.3

31) Flensted-Jensen, Erik: Mit livog mine rejser, eget forlag, København, 1983, p. 37

32) Brev fra H. M. Kong Christian X.'s Kabinetsekretær, Kammerherre G. Bardenfleth, Amalienborg, den 31. Juli 1944.

33) Thomsen, Arne: Drommerejsen - med FlenstedJensens gymnastikhold gennem USA - Canada Vestindien-Sydamerika, Arne og Arnold Thomsen, Esbjerg, 1971, pp. 83-84

34) Erik Flensted-Jensen: Åbent brev til Danmarks regering og Folketing, Virum, den 29 august 1973

35) Erik Flensted-Jensen: Efterlysning: Ny værdighed $i$ den vestlige verden. Åbent brev til Danmarks Regering og Folketing. Emne: Situationen omkring Israel. Virum, april 1982

36) DR TV-sporten, portrætudsendelse, Flik-flak Flensted, producer Hans Gronfelt, 1987

37) Educational Cruises-To Educators and other People whom it may concern, by Erik Flensted-Jensen, February 1967

38) Thomsen, Arne: Drommerejsen - med FlenstedJensens gymnastikhold gennem USA - Canada Vestindien-Sydamerika, Arne og Arnold Thomsen, Esbjerg, 1971, pp. 153-154 
